\title{
Dejavniki, \\ ki ovirajo zaposlene pri izobraževanju
}

Jasmina Starc, mag. Ana

Blažič

Visoka šola za upravljanje in poslovanje, Novo mesto strokovni literaturi so raznolike klasifikacije ovir za izobraževanje, vendar se v vseh poskusih razvrščanja pojavljajo tako imenovane situacijske, institucijske in dispozicijske ovire.

Situacijske ovire izhajajo iz posameznikovega trenutnega razpoloženja in zajemajo predvsem pomanjkanje časa, stroške izobraževanja, družinske obveznosti, oddaljenost izobraževalnih ustanov.

Institucijske ovire zajemajo ponudbo ustreznih študijskih programov ali tečajev, možnosti vpisnih pogojev, urnike predavanj, način prenašanja znanja, informiranost o možnostih izobraževanja, učne metode ter oblike, predavatelje in prostor. Programi odraslim pogosto niso dovolj prilagojeni, tako da ne zadovoljijo potreb posameznikov. Sem štejemo tudi prezahtevnost programov, kar je domena presoje posameznika, ki meni, da nima dovolj lastnih zmogljivosti za obvladanje določenega programa.

Dispozicijske ovire so povezane s psihološkimi značilnostmi posameznikov, kot so podoba o samem sebi, samozavest, stopnja aspiracije, stališča, zmožnosti za učenje, odnos do izobraževanja, strah pred izpiti, starost in predizobrazba. Mnoge posameznike je strah pred izpiti, pri čemer se v tej oviri gotovo skrivajo tudi neugodne izkušnje pri izobraževanju $\mathrm{v}$ preteklosti. Miselnost, da je nekdo prestar za učenje, izhaja iz prevladujoče izobraževalne tradicije, da sta učenje in izobraževanje samo za mlade.

\section{METODOLOGIJA RAZISKOVANIA}

Populacijo našega raziskovanja sestavljajo izredni študentje drugih letnikov na samostojnih visokošolskih zavodih v RS v študijskem letu 2000/01 (Visoka šola za upravljanje in poslovanje Novo mesto, Visoka strokovna šola za podjetništvo $\mathrm{v}$ Portorožu, Visoka šola za turizem Portorož, Visoka šola za management $\mathrm{v}$ Kopru). Ker smo želeli priti na podlagi podatkov vzorca do čim natančnejših spoznanj o populaciji, smo izbrali enote vzorca tako, da je bil le-ta reprezentativen. Vzorec anketiZaposleni pri
izobraževanju
naletijo na
situacijske,
institucijske in
dispozicijske ovire. ranih $(n=400)$ pomeni 73,8 odstotka celotne populacije izrednih študentov drugih letnikov, ki se izobražujejo na petih samostojnih visokošolskih zavodih v Sloveniji. Za vzorec smo si izbrali študente drugih letnikov, ker so bili ti dovolj motivirani, da so končali prvi letnik, in ker imajo o študiju dovolj informacij in lastnih izkušenj.

\section{REZULTATI IN INTERPRETACIJA}

Ker smo želeli ugotoviti, katere ovire jim otežujejo študij, smo jim ponudili lestvico situacijskih, institucijskih in dispozicijskih ovir. Odločili so se lahko za tri vnaprej naštete kategorije ovir. Izhajali smo iz hipoteze, da pri udeležencih izobraževanja prevladujejo na-
As 42 
slednje situacijske ovire: pomanjkanje časa, stroški izobraževanja, oddaljenost od izobraževalne ustanove in družinske obveznosti. Predpostavljali smo tudi, da so razlike v odgovorih odvisne od spola, starosti, zakonskega stana in števila otrok.

Z raziskavo smo ugotovili, da na izredne študente pri študiju najbolj vplivajo situacijske ovire: pomanjkanje časa $(66,5$ odstotka anketiranih), stroški izobraževanja ( 55,1 odstotka), oddaljenost od izobraževalne ustanove $(14,1$ odstotka) in družinske obveznosti (11,3 odstotka).

Tak rezultat je bil pričakovan, saj so izredni študenti praviloma zaposleni in morajo usklajevati službene obveznosti s študijskimi, za to pa jim pogosto zmanjkuje časa, saj ima služba že zaradi eksistenčnih razlogov ponavadi prednost pred študijem. Tisti, ki imajo tudi družino in sodelujejo še v različnih drugih organizacijah ter klubih, pa so še toliko bolj časovno omejeni in še teže najdejo čas za študij in redno opravljanje študijskih obveznosti. Stroški izobraževanja so od nekdaj pomenili precejšnjo oviro. To pomeni, da je šolnina za izredni študij visoka, s seboj prinese še kopico drugih stroškov, ki si jih 51,8 odstotka anketiranih študentov plačuje sama. Ker skoraj polovica študentov ( 48,8 odstotka) ni na vodilnih delovnih mestih in ker jih kar 30 odstotkov ni zaposlenih, ti nimajo prav visokih prihodkov ali pa jih kot brezposelni sploh nimajo. Zato je razumljivo, da so za njih stroški izobraževanja resna ovira pri študiju.

Oddaljenost od izobraževalne ustanove je ovira za 14,1 odstotka respondentov. Dobri dve tretjini (67,5 odstotka) izrednih študentov je oddaljenih od šole do 35 kilometrov, kar je razmeroma blizu. Njim oddaljenost od šole ne pomeni večje ovire pri samem študiju, obiskovanju predavanj ali seminarskih vaj. Preostala tretjina izrednih študentov, 32,5 odstotka, pa je od šole oziroma kraja izvajanja študijskega programa oddaljena 36 kilometrov in več, kar pa že pomeni določeno oviro, saj porabijo samo za vožnjo v eno smer skoraj eno uro ali pa celo več. Pogoj za obiskovanje študija je prevozno sredstvo in navsezadnje tudi dovolj visok osebni dohodek za pokritje stroškov, povezanih s prevozom. Kot četrto najpogostejšo oviro navajajo predvsem poročeni anketiranci družinske obveznosti, kot so majhni otroci, bolezen, neurejeno varstvo za otroke, delavnik zakonskega partnerja ipd.

Podatki potrjujejo našo predpostavko, da odrasle pri odločanju za izobraževanje najbolj ovirajo situacijske ovire. Da bi lahko potrdili oziroma ovrgli drugi del hipoteze, smo opravili Kullbackov test med štirimi najpogostejšimi situacijskimi ovirami in neodvisnimi spremenljivkami: spol, starost, število otrok in zakonski stan.

Statistično pomembne razlike pri pomanjkanju časa se v celotnem vzorcu kažejo glede na starost, spol, zakonski stan in število otrok. Pomanjkanje časa za izobraževanje ovira mnogo bolj ženske kot moške $\left(\chi^{2}=8,389>\right.$ $\left.\chi^{2} 0,05\right)$ in tiste, ki imajo dva otroka $\left(\chi^{2}=\right.$ $\left.20,256>\chi^{2} 0,01\right)$, kar je razumljivo in pričakovano. Ženske imajo poleg službenih obveznosti še obveznosti doma, ki so večinoma na njihovih ramenih, kljub temu si svoje delo organizirajo tako, da lahko obiskujejo predavanja in opravljajo študijske obveznosti, kar pomeni, da so tudi bolje motivirane za študij. Pri študiju najbolj ovira pomanjkanje časa mlajše respondente (26-35 let), najmanj pa tiste, ki so stari 46 let in več $\left(\chi^{2}=15,229>\chi^{2} 0,05\right)$. To ugotovitev lahko povežemo s tem, da se mladi, ki so neporočeni in stari od 26 do 35 let, želijo družiti s svojimi vrstniki neodvisno od študijskih obveznosti, ki jih imajo med študijem. Tisti, ki so v tej starosti nezaposleni, si iščejo priložnostno delo, ki ga opravljajo tudi $\mathrm{v}$ času, ko bi morali biti na predavanjih ali pa se pripravljati na izpite. Anketiranci, stari od 26 do 35 let, pa imajo v tem obdobju majhne otroke in kopico skrbi ter obveznosti, ki jih pomeni družinsko življenje. Bolezni otrok, 
zunajšolske dejavnosti otrok in partnerjevih obveznosti ravno tako ovirajo izobraževanca pri njegovem študiju. Tisti, ki so neporočeni, pogosteje trdijo, da jih pri študiju ovira pomanjkanje časa $\left(\chi^{2}=17,017>\chi^{2} 0,01\right)$, čeprav imajo več časa in manj obveznosti kot njihovi poročeni kolegi ali pa tisti, ki so $\mathrm{v}$ zunajzakonski zvezi. Predvidevamo lahko, da si zaradi razpršenih interesov ne znajo ustrezno razporediti časa in ga pogosteje porabijo za druženje s prijatelji in priložnostno delo (predvsem tisti, ki so nezaposleni) kot za študij.

Stroški izobraževanja bolj ovirajo ženske $\left(\chi^{2}=12,815>\chi^{2} 0,01\right)$, pa tudi respondente $\mathrm{v}$ starosti do 25 let, saj jih je kar 66,7 odstotka navedlo, da so največja ovira prav stroški ( $\chi^{2}$ $=18,102>\chi^{2}$ 0,01). Med tistimi, ki so stari od 26 do 35 let, je navedlo, da so največja ovira stroški izobraževanja - 25,4 odstotka, v starosti med 36. in 45 . letom 7 odstotkov in nad 46 let 0,9 odstotka. Mlajši, stari do 25 let, se šele osamosvajajo in navajajo na samostojno življenje. Materialno še niso preskrbljeni, veliko jih nima zagotovljene službe in so brez rednih mesečnih dohodkov. Stroški izobraževanja so največja ovira za neporočene $\left(\chi^{2}=26,542>\right.$ $\chi^{2}$ 0,001). To lahko razložimo s tem, da je med neporočenimi največ mladih do 25 let, ki nimajo zagotovljenih eksistenčnih možnosti in so finančno odvisni od staršev, priložnostnega dela in pomoči zavoda za zaposlovanje.

Kullbackov test verjetnosti povezave med spremenljivkami v celotnem vzorcu je pokazal, da se podatki o stopnji intenzivnosti ovire oddaljenost šole od doma statistično niso pomembno razlikovali glede na starost, zakonski stan in število otrok. Razlika se je pokazala samo glede na spol. Ovira je bolj moteča za ženske $\left(\chi^{2}=12,217>\chi^{2} 0,001\right)$. To lahko razložimo s tem, da je zanje vožnja poleg obveznosti na delovnem mestu in obremenitve doma le nepotrebna izguba časa.

Statistično pomembne razlike pri oviri družinske obveznosti se v celotnem vzorcu kaže- jo samo glede na spol $\left(\chi^{2}=7,239>\chi^{2} 0,05\right)$. Pri drugih primerjalnih lastnostih (starost, zakonski stan, število otrok) nismo ugotovili statistično pomembnih razlik.

\section{SKLEPNE MISLI}

Pri izobraževanju odraslih moramo upoštevati, da sočasno in tudi v njegovem okviru nastajajo antimotivi oziroma ovire, ki znižujejo stopnjo motivacije. Pogosto onemogočajo tudi redno udeležbo v izobraževalnem procesu. Ovire so v strokovni literaturi različno klasificirane in zelo neenotno opredeljene. Raziskava je pokazala, da je delitev na situacijske ovire, ki izhajajo iz posameznikovega trenutnega razpoloženja, institucijske ovire, ki zajemajo ponudbo ustreznih študijskih programov, možnosti vpisnih pogojev ter načine prenašanja znanja, in dispozicijske ovire, povezane s psihološkimi značilnostmi odraslega, za namen našega raziskovanja ustrezna. Ugotovili smo, da izhaja največ motečih dejavnikov iz situacijskih ovir, sledijo pa jim institucujske in dispozicijske ovire.

\section{LITERATURA}

Brečko, D. (1998). Kako se odrasli spreminjamo: socialna komunikacija in osebnostni razvoj. Radovljica: Didakta.

Daines, J. in drugi (1993). Adult learning adult teaching. Nottingham: Department of Adult Education.

Jelenc, S. (1996). ABC izobraževanja odraslih. Ljubljana: Andragoški center RS.

Jelenc, Z. (1989). Odrasli prebivalci Slovenije v izobraževanju. Ljubljana: Skupnost izobraževalnih centrov $v$ Sloveniji.

Jelenc, Z. (1989). Izobraževanje delavcev v delovnih organizacijah v Sloveniji. Ljubljana: Pedagoški inštitut pri Univerzi Edvarda Kardelja.

McGivney, V. (1990). Access to education for non-participant adults. Leicester: Niace.

Rogers, J. (1992). Adults learning. Milton Keynes: Open University Press. 